\title{
Aflatoxins: A Global Concern for Food Safety, Human Health and Their Management
}

\author{
Pradeep Kumar $^{1 *}$, Dipendra K. Mahato ${ }^{2}$, Madhu Kamle ${ }^{1 *}$, Tapan K. Mohanta ${ }^{3 *}$ and \\ Sang G. Kang ${ }^{3 *}$
}

${ }^{1}$ Department of Forestry, North Eastern Regional Institute of Science and Technology, Nirjuli, India, ${ }^{2}$ Division of Food Science \& Postharvest Technology, Indian Agricultural Research Institute, New Delhi, India, ${ }^{3}$ Department of Biotechnology, Yeungnam University, Gyeongsan, South Korea

\section{OPEN ACCESS}

Edited by:

Bhim Pratap Singh,

Mizoram University, India

Reviewed by:

Giuseppe Spano,

University of Foggia, Italy

Mohd Adil,

Dalhousie University, Canada

*Correspondence:

Pradeep Kumar

pkbiotech@gmail.com

Madhu Kamle

madhu.kamle18@gmail.com

Tapan K. Mohanta

nostoc.tapan@gmail.com

Sang G. Kang

kangsg@yu.ac.kr

Specialty section:

This article was submitted to Microbiotechnology, Ecotoxicology

and Bioremediation,

a section of the journal

Frontiers in Microbiology

Received: 07 October 2016

Accepted: 23 December 2016

Published: 17 January 2017

Citation:

Kumar P, Mahato DK, Kamle M,

Mohanta TK and Kang SG (2017)

Aflatoxins: A Global Concern for Food

Safety, Human Health and Their

Management.

Front. Microbiol. 7:2170.

doi: 10.3389/fmicb.2016.02170
The aflatoxin producing fungi, Aspergillus spp., are widely spread in nature and have severely contaminated food supplies of humans and animals, resulting in health hazards and even death. Therefore, there is great demand for aflatoxins research to develop suitable methods for their quantification, precise detection and control to ensure the safety of consumers' health. Here, the chemistry and biosynthesis process of the mycotoxins is discussed in brief along with their occurrence, and the health hazards to humans and livestock. This review focuses on resources, production, detection and control measures of aflatoxins to ensure food and feed safety. The review is informative for health-conscious consumers and research experts in the fields. Furthermore, providing knowledge on aflatoxins toxicity will help in ensure food safety and meet the future demands of the increasing population by decreasing the incidence of outbreaks due to aflatoxins.

Keywords: aflatoxins, health issues, Aspergillus sp., secondary metabolites, food contamination

\section{INTRODUCTION}

Aflatoxins are one of the highly toxic secondary metabolites derived from polyketides produced by fungal species such as Aspergillus flavus, A. parasiticus, and A. nomius (Payne and Brown, 1998). These fungi usually infect cereal crops including wheat, walnut, corn, cotton, peanuts and tree nuts (Jelinek et al., 1989; Severns et al., 2003), and can lead to serious threats to human and animal health by causing various complications such as hepatotoxicity, teratogenicity, and immunotoxicity (Figure 1) (Amaike and Keller, 2011; Kensler et al., 2011; Roze et al., 2013). The major aflatoxins are B1, B2, G1, and G2, which can poison the body through respiratory, mucous or cutaneous routes, resulting in overactivation of the inflammatory response (Romani, 2004).

Food safety is one of the major problems currently facing the world; accordingly, a variety of studies have been conducted to discuss methods of addressing consumer concerns with various aspects of food safety (Nielsen et al., 2009). Since 1985, the United States Food and Drug Administration (USFDA) has restricted the amount of mycotoxins permitted in food products. The USDA Grain and Plant Inspection Service (GPIS) have implemented a service laboratory for inspection of mycotoxins in grains. Additionally, the Food and Agricultural Organization (FAO) and World Health Organization (WHO) have recognized many toxins present in agricultural products. When mycotoxins are contaminated into foods, they cannot be destroyed by normal cooking processes. However, there have been many recent advances in food processing developed 


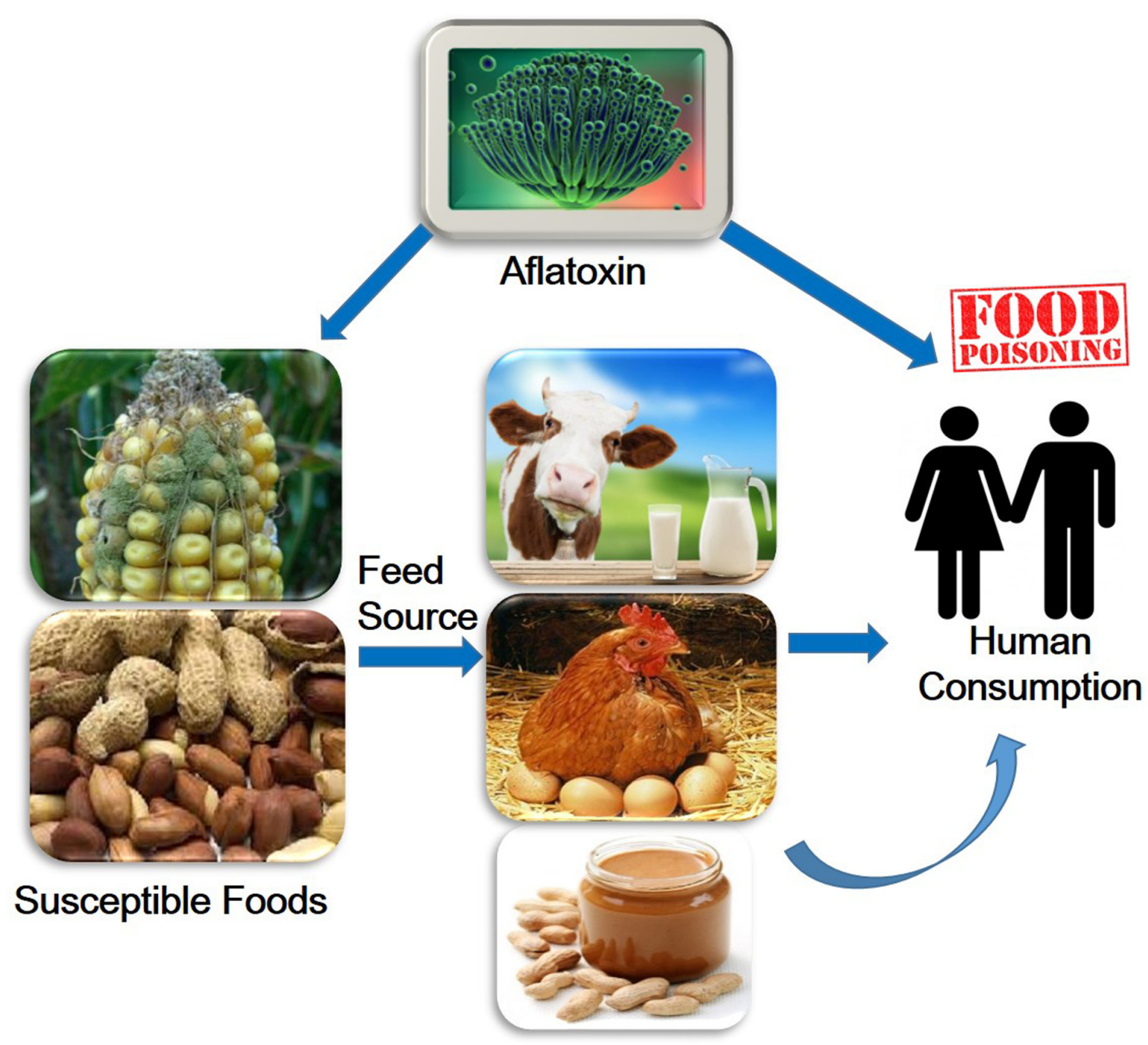

FIGURE 1 | Overview of aflatoxin effects on humans.

to keep final food products safe and healthy, such as hazard analysis of critical control points (HACCP) and good manufacturing practices (GMP; Lockis et al., 2011; Cusato et al., 2013; Maldonado-Siman et al., 2014). Moreover, several physical, chemical and biological methods can be applied to partially or completely eliminate these toxins from food and guarantee the food safety and health concerns of consumers. This review provides an overview of aflatoxigenic fungi, chemistry and biosynthesis of aflatoxins, along with their diversity in occurrence, and their health related risks to humans and livestock. Moreover, the effects of processing techniques on aflatoxins and various physical, chemical and biological methods for their control and management in food are discussed briefly.

\section{OUTBREAKS DUE TO AFLATOXINS}

In 1974, a major outbreak of hepatitis due to aflatoxin was reported in the states of Gujrat and Rajasthan in India, resulting in an estimated 106 deaths (Krishnamachari et al., 1975). The outbreak lasted for 2 months and was confined to tribal people whose main staple food, maize, was later confirmed to contain aflatoxin. The preliminary analysis confirmed that consumption of A. flavus had occurred (Krishnamachari et al., 1975; Bhatt and Krishnamachari, 1978). Another outbreak of aflatoxin affecting both humans and dogs was reported in northwest India in 1974 (Tandon et al., 1977; Bhatt and Krishnamachari, 1978; Reddy and Raghavender, 2007). A major aflatoxin exposure outbreak was subsequently documented in Kenya in 1981 (Ngindu et al., 1982). Since 2004, multiple aflatoxicosis outbreaks have been reported worldwide, resulting in 500 acute illness and 200 deaths (Centers for Disease Control and Prevention [CDCP], 2004; Azziz-Baumgartner et al., 2005). Most outbreaks have been reported from rural areas of the East Province of Kenya in 2004 and occurred because of consumption of home grown maize contaminated with molds. Preliminary testing of food from affected areas revealed the presence of aflatoxin as reported in 1981 (Ngindu et al., 1982). 
In 2013, countries in Europe including Romania, Serbia, and Croatia reported the nationwide contamination of milk with aflatoxin ${ }^{1}$.

\section{MAJOR SOURCE OF AFLATOXIN}

The major sources of aflatoxins are fungi such as A. flavus, A. parasiticus, and A. nomius (Kurtzman et al., 1987), although they are also produced by other species of Aspergillus as well as by Emericella spp. (Reiter et al., 2009). There are more than 20 known aflatoxins, but the four main ones are aflatoxin B1 (AFB1), aflatoxin B2 (AFB2), aflatoxin G1 (AFG1), and aflatoxin G2 (AFG2; Inan et al., 2007), while aflatoxin M1 (AFM1) and M2 (AFM2) are the hydroxylated metabolites of AFB1 and AFB2 (Giray et al., 2007; Hussain and Anwar, 2008).

\section{Aspergillus spp.}

The Aspergillus species are an industrially important group of microorganisms distributed worldwide. A. niger has been given Generally Recognized as Safe (GRAS) status by the USFDA (Schuster et al., 2002). However, some species have negative impacts and cause diseases in grape, onion, garlic, peanut, maize, coffee, and other fruits and vegetables (Lorbeer et al., 2000; Magnoli et al., 2006; Waller et al., 2007; Rooney-Latham et al., 2008). Moreover, Aspergillus section nigri produces mycotoxins such as ochratoxins and fumonisins in peanut, maize, and grape (Astoreca et al., 2007a,b; Frisvad et al., 2007; Mogensen et al., 2009).

Plant-pathogen interactions have been studied using molecular markers such as green fluorescent protein (GFP) isolated from Aequorea victoria (Prasher et al., 1992). The GFP gene has been successfully inserted into Undifilum oxytropis (Mukherjee et al., 2010), Fusarium equiseti (Macia-Vicente et al., 2009), and Muscodor albus (Ezra et al., 2010) and utilized to study the expression of different proteins and production of mycotoxins. A. flavus and A. parasiticus infect many crops in the field, during harvest, in storage, and during processing. A. flavus is dominant in corn, cottonseed, and tree nuts, whereas $A$. parasiticus is dominant in peanuts. A. flavus consists of mycelium, conidia, or sclerotia and can grow at temperatures ranging between 12 and $48^{\circ} \mathrm{C}$ (Hedayati et al., 2007). A. flavus produces AFBI and AFB2, whereas A. parasiticus isolates produce AFGI, AFG2, AFM1, AFBI, and AFB2. A. flavus produces a number of airborne conidia and propagules that infect plants such as cotton (Lee et al., 1986). A high number of propagules was reported in soil, air, and on cotton leaves during mid- to late August, while soilborne inoculum increased drastically between April and December in cotton fields in Arizona (Ashworth et al., 1969). This fungus can even colonize moribund rye cover crop and peanut fruit debris (Griffin and Garren, 1976).

\footnotetext{
${ }^{1}$ https://en.wikipedia.org/wiki/2013_European_aflatoxin_contamination
}

\section{AFLATOXIN (AFT)}

Among the mycotoxins affecting food and feed, aflatoxin is the major one in food that ultimately harms human and animal health (Boutrif, 1998). The level of toxicity associated with aflatoxin varies with the types present, with the order of toxicity being AFTs- $B_{1}>$ AFTs $-G_{1}>$ AFTs- $B_{2}>$ AFTs- $G_{2}$ (Jaimez et al., 2000).

\section{CHEMISTRY AND BIOSYNTHESIS OF AFLATOXINS}

Chemically, aflatoxins (AFTs) are difuranocoumarin derivatives in which a bifuran group is attached at one side of the coumarin nucleus, while a pentanone ring is attached to the other side in the case of the AFTs and AFTs-B series, or a six-membered lactone ring is attached in the AFTs-G series (Bennett and Klich, 2003; Nakai et al., 2008). The physical, biological and chemical conditions of Aspergillus influence the production of toxins. Among the 20 identified AFTs, AFT- $B_{1}$, and AFT- $B_{2}$ are produced by $A$. flavus, while AFT-G $\mathrm{G}_{1}$ and $A F T-\mathrm{G}_{2}$ along with AFT- $B_{1}$ and AFT- $B_{2}$ are produced by $A$. parasiticus (Bennett and Klich, 2003). AFT-B , AFT-B $_{2}$, AFT-G , $_{1}$ and AFT- $\mathrm{G}_{2}$ are the four major naturally produced aflatoxins (Pitt, 2000). AFTs$\mathrm{M}_{1}$ and AFTs- $\mathrm{M}_{2}$ are derived from aflatoxin B types through different metabolic processes and expressed in animals and animal products (Weidenborner, 2001; Wolf-Hall, 2010). AFT-B is highly carcinogenic (Squire, 1981), as well as heat resistant over a wide range of temperatures, including those reached during commercial processing conditions (Sirot et al., 2013).

The biosynthetic pathway of aflatoxins consists of 18 enzymatic steps for conversion from acetyl-CoA, and at least 25 genes encoding the enzymes and regulatory pathways have been cloned and characterized (Yu et al., 2002; Yabe and Nakajima, 2004). The gene comprises $70 \mathrm{~kb}$ of the fungal genome and is regulated by the regulatory gene, aflR (Yabe and Nakajima, 2004; Yu et al., 2004; Price et al., 2006). The metabolic grid involved in the aflatoxin biosynthesis (Yabe et al., 1991, 2003). Hydroxyversicolorone (HVN) is converted to versiconal hemiacetal acetate (VHA) by a cytosol monooxygenase, in which NADPH is a cofactor (Yabe et al., 2003). Monooxygenase is encoded by the moxY gene, which catalyzes the conversion of HVN to VHA and the accumulation of HVN and versicolorone (VONE) occurs in the absence of the moxY gene (Wen et al., 2005).

\section{GENE RESPONSIBLE FOR AFLATOXIN PRODUCTION}

Various genes and their enzymes are involved in the production of sterigmatocystin (ST) dihydrosterigmatocystin (DHST), which are the penultimate precursors of aflatoxins (Cole and Cox, 1987). The aflatoxin biosynthesis gene nor-1, which was first cloned in A. Parasiticus, is named after the product formed by the gene during biosynthesis (Chang et al., 1992). 
These genes named according to substrate and the product formed nor-1 (norsolorinic acid [NOR]), norA, norB, avnA (averanti [AVN]), avfA (averufin [AVF]), ver-1 (versicolorin A [VERA]), verA and $\operatorname{ver} B$ while those based on enzyme functions fas-2 (FAS alpha subunit), fas-1 (FAS beta subunit), pksA (PKS), adhA (alcohol dehydrogenase), estA (esterase), vbs (VERB synthase), $d m t A$ (mt-I; O-methyltransferase I), omtA (O-methyltransferase A), ordA (oxidoreductase A), cypA (cytochrome $\mathrm{P} 450$ monooxygenase), cypX (cytochrome $\mathrm{P} 450$ monooxygenase), and moxY (monooxygenase). Initially, the aflatoxin regulatory gene was named afl-2 in A. flavus (Payne et al., 1993) and apa-2 in A. parasiticus (Chang et al., 1993). However, it was subsequently referred to as aflR in A. flavus, $A$. parasiticus, and $A$. nidulans because of its role as a transcriptional activator. Previous studies have shown that aflA (fas-2), aflB (fas-1), and aflC ( $p k s A)$ are responsible for the conversion of acetate to NOR (Townsend et al., 1984; Brown et al., 1996). Moreover, the $u v m 8$ gene was shown to be essential for NOR biosynthesis as well as aflatoxin production in $A$. parasiticus. The amino acid of sequence of the gene is similar to that of the beta subunit of FASs (FAS1) from Saccharomyces cerevisiae (Trail et al., 1995a,b). FAS forms the polyketide backbone during aflatoxin synthesis; hence, the uvm 8 gene was named fas-1 (Mahanti et al., 1996). Fatty acid syntheses (FASs) is responsible for sterigmatocystin (ST) biosynthesis in A. nidulans and further identified two genes viz., stcJ and stcK that encode FAS and FAS subunits (FAS-2 and FAS-1; Brown et al., 1996).

\section{OCCURRENCE IN FOOD}

Aflatoxins are found in various cereals, oilseeds, spices, and nuts (Lancaster et al., 1961; Weidenborner, 2001; Reddy, 2010; Iqbal et al., 2014). These Aspergillus colonize among themselves and produce aflatoxins, which contaminate grains and cereals at various steps during harvesting or storage. Fungal contamination can occur in the field, or during harvest, transport and storage (Kader and Hussein, 2009). Aflatoxins contamination of wheat or barley is commonly happen by the result of inappropriate storage (Jacobsen, 2008). In milk, aflatoxins is generally at $1-6 \%$ of the total content in the feedstuff (Jacobsen, 2008). AFTs infect humans following consumption of aflatoxins contaminated foods such as eggs, meat and meat products, milk and milk products, (Bennett and Klich, 2003; Piemarini et al., 2007).

\section{EFFECTS ON AGRICULTURE AND FOOD}

Mycotoxins, including aflatoxin, have affected most crops grown worldwide; however, the extent of aflatoxin toxicity varies according to the commodities (Abbas et al., 2010). Aflatoxin can infect crops during growth phases or even after harvesting (Kumar et al., 2008). Exposure to this toxin poses serious hazards to human health (Umoh et al., 2011). Commodities such as corn, peanuts, pistachio, Brazil nuts, copra, and coconut are highly prone to contamination by aflatoxin (Idris et al., 2010; Cornea et al., 2011), whereas wheat, oats, millet, barley, rice, cassava, soybeans, beans, pulses, and sorghum are usually resistant to aflatoxin contamination. However, agricultural products such as cocoa beans, linseeds, melon seeds and sunflower seeds are seldom contaminated (Bankole et al., 2010). Aflatoxin was on the Rapid Alert System for Food and Feed (RASFF) of the European Union in 2008 because of its severe effects (European Commission, 2009), and the International Agency for Research on Cancer (IARC) later categorized AFB1 as a group I carcinogen for humans (Seo et al., 2011). Despite several research and control measures, aflatoxin is still a major threat to food and agricultural commodities.

\section{MECHANISM OF TOXICITY AND HEALTH EFFECTS BY AFLATOXIN}

Aflatoxin are specifically target the liver organ (Abdel-Wahhab et al., 2007). Early symptoms of hepatotoxicity of liver caused by aflatoxins comprise fever, malaise and anorexia followed with abdominal pain, vomiting, and hepatitis; however, cases of acute poisoning are exceptional and rare (Etzel, 2002). Chronic toxicity by aflatoxins comprises immunosuppressive and carcinogenic effects. Evaluation of the effects of AFT$\mathrm{B}_{1}$ on splenic lymphocyte phenotypes and inflammatory cytokine expression in male F344 rats have been studied (Qian et al., 2014). AFT-B $B_{1}$ reduced anti-inflammatory cytokine IL-4 expression, but increased the pro-inflammatory cytokine IFN- $\gamma$ and TNF- $\alpha$ expression by NK cells. These findings indicate that frequent $\mathrm{AFT}-\mathrm{B}_{1}$ exposure accelerates inflammatory responses via regulation of cytokine gene expression. Furthermore, Mehrzad et al. (2014) observed that AFT-B 1 interrupts the process of antigen-presenting capacity of porcine dendritic cells, suggested this perhaps one of mechanism of immunotoxicity by AFT-B . $^{2}$

Aflatoxins cause reduced efficiency of immunization in children that lead to enhanced risk of infections (Hendrickse, 1997). The hepatocarcinogenicity of aflatoxins is mainly due to the lipid peroxidation and oxidative damage to DNA (Verma, 2004). AFTs- $B_{1}$ in the liver is activated by cytochrome $p 450$ enzymes, which are converted to AFTs-B1-8, 9-epoxide, which is responsible for carcinogenic effects in the kidney (Massey et al., 1995). Among all major mycotoxins, aflatoxins create a high risk in dairy because of the presence of their derivative, AFTs- $M_{1}$, in milk, posing a potential health hazard for human consumption (Van Egmond, 1991; Wood, 1991). AFTs-B B $_{1}$ is rapidly absorbed in the digestive tract and metabolized by the liver, which converts it to AFT-M for subsequent secretion in milk and urine (Veldman et al., 1992). Although AFTs-M $M_{1}$ is less mutagenic and carcinogenic than AFTs- $\mathrm{B}_{1}$, it exhibits high genotoxic activity. The other effects of AFTs- $\mathrm{M}_{1}$ include liver damage, decreased milk production, immunity suppression and reduced oxygen supply to tissues due to anemia (Aydin et al., 2008), which reduces appetite and growth in dairy cattle (Akande et al., 2006). Several studies have shown the detrimental effects of aflatoxins exposure on the liver (Sharmila Banu et al., 2009), epididymis (Agnes and Akbarsha, 2001), testis (Faisal et al., 2008), 
kidney and heart (Mohammed and Metwally, 2009; Gupta and Sharma, 2011). It has been found that aflatoxin presences in postmortem brain tissue (Oyelami et al., 1995), suggested that its ability to cross the blood brain barrier (Qureshi et al., 2015). AFTs also cause abnormalities in the structure and functioning of mitochondrial DNA and brain cells (Verma, 2004). The effects of aflatoxin on brain chemistry have been reviewed in details by Bbosa et al. (2013). Furthermore, few reports have described the effects of AFTs- $B_{1}$ administration on the structure of the rodent central nervous system (Laag and Abdel Aziz, 2013).

The liver toxicology of aflatoxin is also a critical issue (IARC, 2002; Iqbal et al., 2014). Limited doses are not harmful to humans or animals; however, the doses that do cause-effects diverse among Aflatoxin groups. The expression of aflatoxin toxicity is regulated by factors such as age, sex, species, and status of nutrition of infected animals (Williams et al., 2004). The symptoms of acute aflatoxicosis include oedema, haemorrhagic necrosis of the liver and profound lethargy, while the chronic effects are immune suppression, growth retardation, and cancer (Gong et al., 2004; Williams et al., 2004; Cotty and Jaime-Garcia, 2007).

\section{EFFECTS OF PROCESSING ON AFLATOXIN}

Techniques to eliminate aflatoxin may be either physical or chemical methods. Removing mold-damaged kernels, seeds or nuts physically from commodities has been observed to reduce aflatoxins by $40-80 \%$ (Park, 2002). The fate of aflatoxin varies with type of heat treatment (e.g., cooking, drying, pasteurization, sterilization, and spray drying; Galvano et al., 1996). Aflatoxins decompose at temperatures of $237-306^{\circ} \mathrm{C}$ (Rustom, 1997); therefore, pasteurization of milk cannot protect against AFM1 contamination. Awasthi et al. (2012) reported that neither pasteurization nor boiling influenced the level of AFM1 in bovine milk. However, boiling corn grits reduced aflatoxins by $28 \%$ and frying after boiling reduced their levels by $34-53 \%$ (Stoloff and Trucksess, 1981). Roasting pistachio nuts at $90^{\circ} \mathrm{C}, 120^{\circ} \mathrm{C}$, and $150^{\circ} \mathrm{C}$ for 30,60 and $120 \mathrm{~min}$ was found to reduce aflatoxin levels by 17-63\% (Yazdanpanah et al., 2005). The decrease in aflatoxin content depends on the time and temperature combination. Moreover, alkaline cooking and steeping of corn for the production of tortillas reduces aflatoxin by 52\% (Torres et al., 2001). Hameed (1993) reported reductions in aflatoxin content of $50-80 \%$ after extrusion alone. When hydroxide $(0.7$ and $1.0 \%)$ or bicarbonate $(0.4 \%)$ was added, the reduction was enhanced to $95 \%$. Similar results were reported by Cheftel (1989) for the extrusion cooking of peanut meal. The highest aflatoxin reduction was found to be $59 \%$ with a moisture content of $35 \%$ in peanut meal, and the extrusion variables non-significantly affected its nutritional composition (Saalia and Phillips, 2011a). Saalia and Phillips (2011b) reported an 84\% reduction in aflatoxin of peanut meal when cooked in the presence of calcium chloride.

\section{EFFECTS OF ENVIRONMENTAL TEMPERATURE ON AFLATOXIN PRODUCTION}

Climate change plays a major role in production of aflatoxin from Aspergillus in food crops (Paterson and Lima, 2010, 2011; Magan et al., 2011; Wu F. et al., 2011; Wu S. et al., 2011). Climate change affects the interactions between different mycotoxigenic species and the toxins produced by them in foods and feeds (Magan et al., 2010; Paterson and Lima, 2012). Changes in environmental temperature influence the expression levels of regulatory genes (aflR and aflS) and aflatoxin production in A. flavus and A. parasiticus (Schmidt-Heydt et al., 2010, 2011). A good correlation between the expression of an early structural gene (aflD) and AFB1 has been reported by AbdelHadi et al. (2010). Temperature interacts with water activity $\left(\mathrm{a}_{\mathrm{w}}\right)$ and influences the ratio of regulatory genes (aflR/aflS), which is directly proportional to the production of AFB1 (SchmidtHeydt et al., 2009, 2010). The interactions between water activity and temperature have prominent effect on Aspergillus spp. and aflatoxin production (Sanchis and Magan, 2004; Magan and Aldred, 2007). Increasing the temperature to $37^{\circ} \mathrm{C}$ and water stress significantly reduces the production of AFB1 produced, despite the growth of $A$. flavus under these conditions. The addition of $\mathrm{CO}_{2}$ under the same temperature and water activity enhances AFB1 production (Medina et al., 2014). According to Gallo et al. (2016), fungal biomass and AFB1 production were reported to be highest at $28^{\circ} \mathrm{C}$ and $0.96 a_{\mathrm{W}}$, while no fungal growth or AFB1 production was seen at $20^{\circ} \mathrm{C}$ with $a_{\mathrm{W}}$ values of 0.90 and 0.93 . There was also no AFB1 production observed at $37^{\circ} \mathrm{C}$. Reverse transcriptase quantitative PCR also revealed that the regulatory genes aflR and aflS were highly expressed at $28^{\circ} \mathrm{C}$, while the lowest expression was observed at 20 and $37^{\circ} \mathrm{C}$, suggesting that temperature plays a significant role in gene expression and aflatoxin production (Gallo et al., 2016).

\section{DETECTION TECHNIQUES}

The detection and quantification of aflatoxin in food and feed is a very important aspect for the safety concerns. Aflatoxins are usually detected and identified according to their absorption and emission spectra, with peak absorbance occurring at $360 \mathrm{~nm}$. B toxins exhibit blue fluorescence at $425 \mathrm{~nm}$, while $\mathrm{G}$ toxins show green fluorescence at $540 \mathrm{~nm}$ under UV irradiation. This florescence phenomenon is widely accepted for aflatoxins. Thin layer chromatography (TLC) is among one of the oldest techniques used for aflatoxin detection (Fallah et al., 2011), while high performance liquid chromatography (HPLC), liquid chromatography mass spectroscopy (LCMS), and enzyme linked immune-sorbent assay (ELISA) are the methods most frequently used for its detection (Tabari et al., 2011; Andrade et al., 2013; Sulyok et al., 2015). ELISA can be used to identify aflatoxins based on estimation of AfB1-lysine (metabolite of AFB1 toxin) concentration in the blood. Specifically, the test detects levels of AfB1 in blood as low as $5 \mathrm{pg} / \mathrm{mg}$ albumin, making it a 
cost effective method for routine monitoring that can also be utilized for the detection of hepatitis B virus. Room temperature phosphorescence (RTP) in aflatoxigenic strains grown on media is commonly used in food mycology. Aflatoxins immobilized on resin beads can induce RTP in the presence or absence of oxygen and heavy atoms (Costa-Fernandez and Sanz-Medel, 2000) and also have high sensitivity and specificity (Li et al., 2003). Moreover, several biosensors and immunoassays have been developed to detect ultra-traces of aflatoxins to ensure the food safety.

\section{DEGRADATION KINETICS}

Various treatments including chemical, physical, and biological methods are routinely utilized for effective degradation, mitigation and management of aflatoxin (Shcherbakova et al., 2015). The aflatoxins AFB1 and AFG1 are completely removed by ozone treatment at $8.5-40 \mathrm{ppm}$ at different temperatures, but AFB2 and AFG2 are not affected by this method. The degradation of aflatoxin followed first order kinetic equation. However, microbial and enzymatic degradation is preferred for the biodegradation of aflatoxin due to its eco-friendly nature (Agriopoulou et al., 2016). The bacterium Flavobacterium aurantiacum reportedly removes AFM1 from milk and Nocardia asteroides transforms AFB1 to fluorescent product (Wu et al., 2009). Rhodococcus species are able to degrade aflatoxins (Teniola et al., 2005) and their ability to degrade AFB1 occurs in the following order: $R$. ruber $<R$. globerulus $<R$. coprophilus $<R$. gordoniae $<$ $R$. pyridinivorans and $<R$. erythropolis (Cserhati et al., 2013). Fungi such as Pleurotus ostreatus, Trametes versicolor, Trichosporon mycotoxinivorans, S. cerevisiae, Trichoderma strains, and Armillariella tabescens are known to transform AFB1 into less toxic forms (Guan et al., 2008). Zhao et al. (2011) reported purification of extracellular enzymes from the bacterium Myxococcus fulvus ANSM068 with a final specific activity of $569.44 \times 103 \mathrm{U} / \mathrm{mg}$. The pure enzyme $(100 \mathrm{U} / \mathrm{mL})$ had a degradation ability of $96.96 \%$ for AFG1 and $95.80 \%$ for AFM1 after $48 \mathrm{~h}$ of incubation. Moreover, the recombinant laccase produced by A. niger D15-Lcc2\#3 (118 U/L) was found to lead to a decrease in AFB1 of 55\% within 72 h (Alberts et al., 2009).

\section{MANAGEMENT AND CONTROL STRATEGIES}

The biocontrol principle of competitive exclusion of toxigenic strains of $A$. flavus involves the use of non-toxigenic strains to reduce aflatoxin contamination in maize (Abbas et al., 2006). The use of biocontrol agents such as Bacillus subtilis, Lactobacillus spp., Pseudomonas spp., Ralstonia spp., and Burkholderia spp. are effective at control and management of aflatoxins (Palumbo et al., 2006). Several strains of B. subtilis and P. solanacearum isolated from the non-rhizosphere of maize soil have been reported to eliminate aflatoxin (Nesci et al., 2005). Biological control of aflatoxin production in crops in the US has been approved by the
Environmental Protection Agency and two commercial products based on atoxigenic A. flavus strains are being used (Afla-guard ${ }^{\circledR}$ and $\left.\mathrm{AF}^{\circledR} 6^{\circledR}\right)$ for the prevention of aflatoxin in peanuts, corn, and cotton seed (Dorner, 2009). Good agricultural practices (GAPs) also help control the toxins to a larger extent, such as timely planting, providing adequate plant nutrition, controlling weeds, and crop rotation, which effectively control A. flavus infection in the field (Ehrlich and Cotty, 2004; Waliyar et al., 2013).

Biological control is emerging as a promising approach for aflatoxin management in groundnuts using Trichoderma spp, and significant reductions of $20-90 \%$ infection of aflatoxin have been recorded (Anjaiah et al., 2006; Waliyar et al., 2015). Use of inbred maize lines resistant to aflatoxin has also been employed. Potential biochemical markers and genes for resistance in maize against Aspergillus could also be utilized (Chen et al., 2007). Additionally, biotechnological approaches have been reviewed for aflatoxin management strategies ( $\mathrm{Yu}$, 2012). Advances in genomic technology based research and decoding of the A. flavus genome have supported identification of the genes responsible for production and modification of the aflatoxin biosynthesis process (Bhatnagar et al., 2003; Cleveland, 2006; Holbrook et al., 2006; Ehrlich, 2009). In addition, Wu (2010) suggested that aflatoxin accumulation can be reduced by utilizing transgenic $B t$ maize with insect resistance traits as the wounding caused by insects helps penetrate the Aspergillus in kernels.

\section{CONCLUSION}

Aflatoxins are a major source of disease outbreaks due to a lack of knowledge and consumption of contaminated food and feed worldwide. Excessive levels of aflatoxins in food of non-industrialized countries are of major concern. Several effective physical, chemical, biological, and genetic engineering techniques have been employed for the mitigation, effective control and management of aflatoxins in food. However, developing fungal resistant and insect resistant hybrids/crops to combat pre-harvest infections and their outcome is a major issue of concern. Post-harvest treatments to remove aflatoxins such as alkalization, ammonization, and heat or gamma radiation are not generally used by farmers. However, some of the microorganisms naturally present in soil have the ability to degrade and reduce the aflatoxin contamination in different types of agricultural produce. Therefore, methods of using these organisms to reduce aflatoxin are currently being focused on. Moreover, application of genetic recombination in A. flavus and other species is being investigated for its potential to mitigate aflatoxins to ensure the safety and quality of food.

\section{AUTHOR CONTRIBUTIONS}

PK and DM designed and conceived the experiments and wrote the manuscript. MK, TM, and SK edited and helped in finalizing the manuscript. 


\section{ACKNOWLEDGMENTS}

PK and MK highly grateful to the Director and Head, Department of Forestry, NERIST (Deemed University), Arunachal Pradesh,

\section{REFERENCES}

Abbas, H. K., Reddy, K. R. N., Salleh, B., Saad, B., Abel, C. A., and Shier, W. T. (2010). An overview of mycotoxin contamination in foods and its implications for human health. Toxin Rev. 29, 3-26. doi: 10.3109/15569541003598553

Abbas, H. K., Zablotowicz, R. M., Bruns, H. A., and Abel, C. A. (2006). Biocontrol of aflatoxin in corn by inoculation with non-aflatoxigenic Aspergillus flavus isolates. Biocontrol Sci. Technol. 16, 437-449. doi: 10.1080/09583150500532477

Abdel-Hadi, A., Carter, D., and Magan, N. (2010). Temporal monitoring of the nor1 (aflD) gene of Aspergillus flavus in relation to aflatoxin B1 production during storage of peanuts under different environmental conditions. J. Appl. Microbiol. 109, 1914-1922. doi: 10.1111/j.1365-2672.2010.04820.x

Abdel-Wahhab, M. A., Abdel-Galil, M. M., Hassan, A. M., Hassan, N. H., Nada, S. A., Saeed, A., et al. (2007). Zizyphus spina-christi extract protects against aflatoxin B1-intitiated hepatic carcinogenicity. Afr. J. Tradit. Complement. Altern. Med. 4, 248-256.

Agnes, V. F., and Akbarsha, M. A. (2001). Pale vacuolated epithelial cells in epididymis of aflatoxin-treated mice. Reproduction 122, 629-641. doi: 10.1530/ rep.0.1220629

Agriopoulou, S., Koliadima, A., Karaiskakis, G., and Kapolos, J. (2016). Kinetic study of aflatoxins' degradation in the presence of ozone. Food Control 61, 221-226. doi: 10.1016/j.foodcont.2015.09.013

Akande, K. E., Abubakar, M. M., Adegbola, T. A., and Bogoro, S. E. (2006). Nutritional and health implications of mycotoxin in animal feed. Pak. J. Nutr. 5, 398-403. doi: 10.3923/pjn.2006.398.403

Alberts, J. F., Gelderblom, W. C. A., Botha, A., and van Zyl, W. H. (2009). Degradation of aflatoxin B1 by fungal laccase enzymes. Int. J. Food Microbiol. 135, 47-52. doi: 10.1016/j.ijfoodmicro.2009.07.022

Amaike, S. A., and Keller, N. P. (2011). Aspergillus flavus. Annu. Rev. Phytopathol. 49, 107-133. doi: 10.1146/annurev-phyto-072910-095221

Andrade, P. D., da Silva, J. L. G., and Caldas, E. D. (2013). Simultaneous analysis of aflatoxins B1, B2, G1, G2, M1 and ochratoxin A in breast milk by highperformance liquid chromatography/fluorescence after liquid-liquid extraction with low temperature purification (LLE-LTP). J. Chromatogr. A 1304, 61-68. doi: 10.1016/j.chroma.2013.06.049

Anjaiah, V., Thakur, R. P., and Koedam, N. (2006). Evaluation of bacteria and Trichoderma for biocontrol of pre-harvest seed infection by Aspergillus flavus in groundnut. Biocontrol Sci. Technol. 16, 431-436. doi: 10.1080/ 09583150500532337

Ashworth, L. J. Jr., McMeans, J. L., and Brown, C. M. (1969). Infection of cotton by Aspergillus flavus: epidemiology of the disease. J. Stored Prod. Res. 5, 193-202. doi: 10.1016/0022-474X(69)90033-2

Astoreca, A., Magnoli, C., Barberis, C., Chiacchiera, S. M., Combina, M., and Dalcero, A. (2007a). Ochratoxin A production in relation to ecophysiological factors by Aspergillus section Nigri strains isolated from different substrates in Argentina. Sci. Total Environ. 388, 16-23. doi: 10.1016/j.scitotenv.2007.07.028

Astoreca, A., Magnoli, C., Ramirez, M. L., Combina, M., and Dalcero, A. (2007b). Water activity and temperature effects on growth of Aspergillus niger, A. awamori and A. Carbonarius isolated from different substrates in Argentina. Int. J. Food Microbiol. 119, 314-318.

Awasthi, V., Bahman, S., Thakur, L. K., Singh, S. K., Dua, A., and Ganguly, S. (2012). Contaminants in milk and impact of heating: an assessment study. Indian J. Public Health 56, 95-99. doi: 10.4103/0019-557X.96985

Aydin, A., Gunsen, U., and Demirel, S. (2008). Total aflatoxin B1 and ochratoxin A levels in Turkish wheat flour. J. Food Drug Anal. 16, 48-53.

Azziz-Baumgartner, E., Lindblade, K., Gieseker, K., Rogers, H. S., Kieszak, S., Njapau, H., et al. (2005). Case-control study of an acute aflatoxicosis outbreak, Kenya, 2004. Environ. Health Perspect. 113, 1779-1783.

Bankole, S. A., Adenusi, A. A., Lawal, O. S., and Adesanya, O. O. (2010). Occurrence of aflatoxin B1 in food products derivabl e from 'egusi' melon seeds
India. This research was supported by the Basic Science Research Program through the National Research Foundation of Korea (NRF) funded by the Ministry of Education (NRF-20090070065).

consumed in southwestern Nigeria. Food Control 21, 974-976. doi: 10.1016/j. foodcont.2009.11.014

Bbosa, G. S., Kitya, D., Lubega, A., Ogwal-Okeng, J., Anokbonggo, W. W., and Kyegombe, D. B. (2013). "Review of the biological and health effects of aflatoxins on bodyorgans and body systems," in Aflatoxins - Recent Advances and Future Prospects, ed. M. Razzaghi-Abyaneh (Rijeka: InTech), 239-265.

Bennett, J. W., and Klich, M. (2003). Mycotoxins. Clin. Microbiol. Rev. 16, 497-516. doi: 10.1128/CMR.16.3.497-516.2003

Bhatnagar, D., Ehrlich, K. C., and Cleveland, T. E. (2003). Molecular genetic analysis and regulation of aflatoxin biosynthesis. Appl. Microbiol. Biotechnol. 61, 83-93. doi: 10.1007/s00253-002-1199-x

Bhatt, R. V., and Krishnamachari, K. A. V. R. (1978). Food toxins and disease outbreaks in India. Arogya J. Health Sci. 4, 92-100.

Boutrif, E. (1998). Prevention of aflatoxin in pistachios. Food Nutr. Agric. 21, 32-38.

Brown, D. W., Adams, T. H., and Keller, N. P. (1996). Aspergillus has distinct fatty acid synthases for primary and secondary metabolism. Proc. Natl. Acad. Sci. U.S.A. 19, 14873-14877. doi: 10.1073/pnas.93.25.14873

Centers for Disease Control and Prevention [CDCP] (2004). Outbreak of Aflatoxin Poisoning - Eastern and Central Provinces, Kenya, January-July 2004. Available at: https:/www.cdc.gov/mmwr/preview/mmwrhtml/mm5334a4.htm [accessed October 10, 2016]

Chang, P. K., Cary, J. W., Bhatnagar, D., Cleveland, T. E., Bennett, J. W., Linz, J. E., et al. (1993). Cloning of the Aspergillus parasiticus apa-2 gene associated with the regulation of aflatoxin biosynthesis. Appl. Environ. Microbiol. 59, 3273-3279.

Chang, P. K., Skory, C. D., and Linz, J. E. (1992). Cloning of a gene associated with aflatoxin B1 biosynthesis in Aspergillus parasiticus. Curr. Genet. 21, 231-233. doi: $10.1007 / \mathrm{BF} 00336846$

Cheftel, J. C. (1989). "Extrusion cooking and food safety," in Extrusion Cooking, eds C. Mercier, P. Linko, and J. M. Harper (Eagan, MN: American Association of Cereal Chemists), 435-461.

Chen, Z. Y., Brown, R. L., Damann, K. E., and Cleveland, T. E. (2007). Identification of maiz kernel endosperm proteins associated with resistance to aflatoxin contamination by Aspergillus flavus. Phytopathology 97, 1094-1103. doi: 10. 1094/PHYTO-97-9-1094

Cleveland, T. E. (2006). "The use of crop proteomics and fungal genomics inelucidating fungus-crop interactions," in Proceedings of the Myco-Globe Conference, Bari, 32.

Cole, R. J., and Cox, E. H. (1987). Handbook of Toxic Fungal Metabolites. New York, NY: Academic Press.

Cornea, C. P., Ciuca, M., Voaides, C., Gagiu, V., and Pop, A. (2011). Incidence of fungal contamination in a Romanian bakery: a molecular approach. Rom. Biotechnol. Lett. 16, 5863-5871.

Costa-Fernandez, J. M., and Sanz-Medel, A. (2000). Room temperature phosphorescence biochemical sensors. Quim. Anal. 19, 189-204.

Cotty, P. J., and Jaime-Garcia, R. (2007). Influences of climate on aflatoxin producing fungi and aflatoxin contamination. Int. J. Food Microbiol. 119, 109-115. doi: 10.1016/j.ijfoodmicro.2007.07.060

Cserhati, M., Kriszt, B., Krifaton, C., Szoboszlay, S., Hahn, J., Toth, S., et al. (2013). Mycotoxin-degradation profile of Rhodococcus strains. Int. J. Food Microbiol. 166, 176-185. doi: 10.1016/j.ijfoodmicro.2013.06.002

Cusato, S., Gameiro, A. H., Corassin, C. H., Sant'Ana, A. S., Cruz, A. G., Faria, J. D. A. F., et al. (2013). Food safety systems in a small dairy factory: implementation, major challenges, and assessment of systems' performances. Foodborne Pathog. Dis. 10, 6-12. doi: 10.1089/fpd.2012.1286

Dorner, J. W. (2009). Development of biocontrol technology to manage aflatoxin contamination in peanuts. Peanut Sci. 36, 60-67. doi: 10.3146/AT07-002.1

Ehrlich, K. C. (2009). Predicted roles of uncharacterized clustered genes in aflatoxin biosynthesis. Toxins 1, 37-58. doi: 10.3390/toxins1010037 
Ehrlich, K. K., and Cotty, P. J. (2004). An isolate of Aspergillus flavus used to reduce aflatoxin contamination in cottonseed has a defective polyketide synthase gene. Appl. Microbiol. Biotechnol. 65, 473-478. doi: 10.1007/s00253-004-1670-y

Etzel, R. A. (2002). Mycotoxins. JAMA 287, 425-427. doi: 10.1001/jama.287.4.425

European Commission (2009). The Rapid Alert System for Food and Feed (RASFF) Annual Report 2008. Luxembourg: European Communities.

Ezra, D., Skovorodnikova, J., Kroitor-Keren, T., Denisov, Y., and Liarzi, O. (2010). Development of methods for detection and Agrobacterium-mediated transformation of the sterile, endophytic fungus Muscodor albus. Biocontrol Sci. Technol. 20, 83-97. doi: 10.1080/09583150903420049

Faisal, K., Periasamy, V. S., Sahabudeen, S., Radha, A., Anandhi, R., and Akbarsha, M. A. (2008). Spermatotoxic effect of aflatoxin B1 in rat: extrusion of outer densefibres and associated axonemal microtubule doublets of sperm flagellum. Reproduction 135, 303-310. doi: 10.1530/REP-07-0367

Fallah, A. A., Rahnama, M., Jafari, T., and Saei-Dehkordi, S. S. (2011). Seasonal variation of aflatoxin M1 contamination in industrial and traditional Iranian dairy products. Food Control 22, 1653-1656. doi: 10.1016/j.foodcont.2011.03. 024

Frisvad, J. C., Smedsgaard, J., Samson, R. A., Larsen, T. O., and Thrane, U. (2007). Fumonisin B2 Production by Aspergillus niger. J. Agric. Food Chem. 55, 9727-9732. doi: 10.1021/jf0718906

Gallo, A., Solfrizzo, M., Epifani, F., Panzarini, G., and Perrone, G. (2016). Effect of temperature and water activity on gene expression and aflatoxin biosynthesis in Aspergillus flavus on almond medium. Int. J. Food Microbiol. 217, 162-169. doi: 10.1016/j.ijfoodmicro.2015.10.026

Galvano, F., Galofaro, V., and Galvano, G. (1996). Occurrence and stability of aflatoxin M1 in milk and milk products. A worldwide review. J. Food Prot. 59, 1079-1090. doi: 10.4315/0362-028X-59.10.1079

Giray, B., Girgin, G., Engin, A. B., Aydın, S., and Sahin, G. (2007). Aflatoxin levels in wheat samples consumed in some regions of Turkey. Food Control 18, 23-29. doi: 10.1016/j.foodcont.2005.08.002

Gong, Y., Hounsa, A., Egal, S., Turner, P. C., Sutcliffe, A. E., Hall, A. J., et al. (2004). Postweaning exposure to aflatoxin results in impaired child growth: a longitudinal study in Benin, West Africa. Environ. Health Perspect. 112, 1334-1338. doi: 10.1289/ehp.6954

Griffin, G. J., and Garren, K. H. (1976). Colonization of rye green manure and peanut fruit debris by Aspergillus flavus and Aspergillus niger group in field soils. Appl. Environ. Microbiol. 32, 28-32.

Guan, S., Ji, C., Zhou, T., Li, J., Ma, Q., and Niu, T. (2008). Aflatoxin B1 degradation by Stenotrophomonas maltophilia and other microbes selected using coumarin medium. Int. J. Mol. Sci. 9, 1489-1503. doi: 10.3390/ijms9081489

Gupta, R., and Sharma, V. (2011). Ameliorative effects of tinospora cordifolia root extracton histopathological and biochemical changes induced by aflatoxin-b (1) in mice kidney. Toxicol. Int. 18, 94-98. doi: 10.4103/0971-6580.84259

Hameed, H. G. (1993). Extrusion and Chemical Treatments for Destruction of Aflatoxin in Naturally-Contaminated Corn. Ph.D. thesis, University of Arizona, Tucson, AZ.

Hedayati, M. T., Pasqualotto, A. C., Warn, P. A., Bowyer, P., and Denning, D. W. (2007). Aspergillus flavus: human pathogen, allergen and micotoxin producer. Microbiology 153, 1677-1692. doi: 10.1099/mic.0.2007/007641-0

Hendrickse, R. G. (1997). Of sick Turkeys, Kwashiorkor, malaria, perinatal mortality, Herion addicts and food poisoning: research on influence of aflatoxins on child health in the tropics. J. Trop. Med. Parasitol. 91, 87-93.

Holbrook, C. C. Jr., Guo, B., Wilson, D. M., and Timper, P. (2006). "The U.S. breeding program to develop peanut with drought tolerance and reduced aflatoxin contamination [abstract]," in Proceedings of the International Conference on Groundnut Aflatoxin Management and Genomics, Guangzhou.

Hussain, I., and Anwar, J. (2008). A study on contamination of aflatoxin M1 in raw milk in the Punjab province of Pakistan. Food Control 19, 393-395. doi: 10.1016/j.foodcont.2007.12.002

IARC (2002). Monographs on the Evaluation of Carcinogenic Risks to Humans, Vol. 82. Lyon: International Agency for Cancer Research.

Idris, Y. M. A., Mariod, A. A., Elnour, I. A., and Mohamed, A. A. (2010). Determination of aflatoxin levels in Sudanese edible oils. Food Chem. Toxicol. 48, 2539-2541. doi: 10.1016/j.fct.2010.05.021

Inan, F., Pala, M., and Doymaz, I. (2007). Use of ozone in detoxification of aflatoxin B1 in red pepper. J. Stored Prod. Res. 43, 425-429. doi: 10.1016/j.jspr.2006.11. 004
Iqbal, S. Z., Mustafa, H. G., Asi, M. R., and Jinap, S. (2014). Variation in vitamin $\mathrm{E}$ level and aflatoxins contamination in different rice varieties. J. Cereal Sci. 60, 352-355. doi: 10.1016/j.jcs.2014.05.012

Jacobsen, B. J. (2008). "Predicting the Incidence of Mycotoxins," in Proceeding of 26th Annual International Symposium on Man and His Environment in Health and Disease: Molds \& Mycotoxins, Hidden Connections for Chronic Diseases, (Dallas, TX: American Environmental Health Foundation), 13-17.

Jaimez, J., Fente, C. A., Vazquez, B. I., Franco, C. M., Cepeda, A., Mahuzier, G., et al. (2000). Application of the assay of aflatoxins by liquid chromatography with fluorescence detection in food analysis. J. Chromatogr. A 882, 1-10. doi: 10.1016/S0021-9673(00)00212-0

Jelinek, C. F., Pohland, A. E., and Wood, G. E. (1989). Worldwide occurrence of mycotoxins in foods and feeds - an update. J. Assoc. Off. Anal. Chem. 72, 223-230.

Kader, A. A., and Hussein, A. M. (2009). Harvesting and Postharvest Handling of Dates. Aleppo: ICARDA.

Kensler, T. W., Roebuck, B. D., Wogan, G. N., and Groopman, J. D. (2011). Aflatoxin: a 50-year odyssey of mechanistic and translational toxicology. Toxicol. Sci. 120, 28-48. doi: 10.1093/toxsci/kfq283

Krishnamachari, K. A. V. R., Bhat, R. V., Nagarajan, V., and Tilak, T. B. G. (1975). Hepatitis due to aflatoxicosis-An outbreak in western India. Lancet 1, 1061-1063. doi: 10.1016/S0140-6736(75)91829-2

Kumar, V., Basu, M. S., and Rajendran, T. P. (2008). Mycotoxin research and mycoflora in some commercially important agricultural commodities. Crop Prot. 27, 891-905. doi: 10.1016/j.cropro.2007.12.011

Kurtzman, C. P., Horn, B. W., and Hesseltine, C. W. (1987). Aspergillus nomius, a new aflatoxin-producing species related to Aspergillus flavus and Aspergillus parasiticus. Antonie Van Leeuwenhoek 53, 147-158. doi: 10.1016/ S0168-6496(03)00154-5

Laag, E. M., and Abdel Aziz, H. O. (2013). Effect of aflatoxin-B1 on rat cerebellar cortex: light and electron microscopic study. Egypt. J. Histol. 36, 601-610. doi: 10.1097/01.EHX.0000432619.75801.15

Lancaster, M. C., Jenkins, F. P., and Philip, J. M. C. (1961). Toxicity associated with certain samples of ground nuts. Nature 12, 1095-1096. doi: 10.1038/1921095a0

Lee, L. S., Goynes, W. R., and Lacey, P. E. (1986). Aflatoxin in Arizona cottonseed: simulation of insect vectored infection of cotton bolls by Aspergillus flavus. J. Am. Oil Chem. Soc. 63:468.

Li, G. R., Wu, J. J., Jin, W. J., and Xie, J. W. (2003). Antioxygen quenching room temperature phosphorescence stabilized by deoxycholate aggregate. Talanta 60 , 552-562. doi: 10.1016/S0039-9140(03)00185-1

Lockis, V. R., Cruz, A. G., Walter, E. H., Faria, J. A., Granato, D., and Sant'Ana, A. S. (2011). Prerequisite programs at schools: diagnosis and economic evaluation. Foodborne Pathog. Dis. 8, 213-220. doi: 10.1089/fpd.2010.0645

Lorbeer, J. W., Ransom, V. E., and Tuffley, J. J. (2000). Nature and source of Inoculums of Aspergillus niger Causing the Aspergillus Black Mold Disease of Onions in New York. Geneva, NY: New York State Integrated Pest Management Grants Program, 1-6.

Macia-Vicente, J. G., Jansson, H. B., Talbot, N. J., and Lopez-Llorca, L. V. (2009). Real-time PCR quantification and live-cell imaging of endophytic colonization of barley (Hordeumvulgare) roots by Fusarium equiseti and Pochonia chlamydosporia. New Phytol. 182, 213-228. doi: 10.1111/j.1469-8137. 2008.02743.x

Magan, N., and Aldred, D. (2007). Post-harvest control strategies: minimizing mycotoxins in the food chain. Int. J. Food Microbiol. 119, 131-139. doi: 10.1016/ j.ijfoodmicro.2007.07.034

Magan, N., Aldred, D., Hope, R., and Mitchell, D. (2010). Environmental factors and interactions with mycoflora of grain and grapes: effects on growth and deoxynivalenol and ochratoxin production by Fusarium culmorum and Aspergillus carbonarius. Toxins 2, 353-366. doi: 10.3390/toxins2030353

Magan, N., Medina, A., and Aldred, D. (2011). Possible climate change effects on mycotoxin contamination of food crops pre- and post-harvest. Plant Pathol. 60, 150-163. doi: 10.1111/j.1365-3059.2010.02412.x

Magnoli, C., Astoreca, A., Ponsone, L., Fernandez-Juri, M. G., Chiacchiera, S., and Dalcero, A. (2006). Ochratoxin A and the occurrence of ochratoxin A-producing black aspergilla in stored peanut seeds from Cordoba, Argentina. J. Sci. Food Agric. 86, 2369-2373. doi: 10.1002/jsfa.2625

Mahanti, N., Bhatnagar, D., Cary, J. W., Joubran, J., and Linz, J. E. (1996). Structure and function of fas- $1 \mathrm{~A}$, a gene encoding a putative fatty acid synthetase directly 
involved in aflatoxin biosynthesis in Aspergillus parasiticus. Appl. Environ. Microbiol. 62, 191-195.

Maldonado-Siman, E., Bai, L., Ramírez-Valverde, R., Gong, S., and Rodríguezde Lara, R. (2014). Comparison of implementing HACCP systems of exporter Mexican and Chinese meat enterprises. Food Control 38, 109-115. doi: 10.1016/ j.foodcont.2013.10.017

Massey, T. E., Stewart, R. K., Daniels, J. M., and Liu, L. (1995). Biochemical and molecular aspects of mammalian susceptibility to aflatoxin B-1 Carcinogenicity. Proc. Soc. Exp. Biol. Med. 208, 213-227. doi: 10.3181/00379727-208-43 $852 \mathrm{~A}$

Medina, A., Rodriguez, A., and Magan, N. (2014). Effect of climate change on aspergillus flavus and aflatoxin B1 production. Front. Microbiol. 5:348. doi: 10.3389/fmicb.2014.00348

Mehrzad, J., Devriendt, B., Baert, K., and Cox, E. (2014). Aflatoxin B1 interferes with the antigen-presenting capacity of porcine dendritic cells. Toxicol. Vitro 28, 531-537. doi: 10.1016/j.tiv.2013.11.015

Mogensen, J. M., Frisvad, J. C., Thrane, U., and Nielsen, K. F. (2009). Production of fumonisin B2 and B4 by Aspergillus niger on grapes and raisins. J. Agric. Food Chem. 58, 954-958. doi: 10.1021/jf903116q

Mohammed, A. M., and Metwally, N. S. (2009). Antiaflatoxicogenic activities of someaqueous plant extracts against AFB1 induced renal and cardiac damage. J. Pharmacol. Toxicol. 4, 1-16. doi: 10.3923/jpt.2009.1.16

Mukherjee, S., Dawe, A. L., and Creamer, R. (2010). Development of a transformation system in the swainsonine producing, slow growing endophytic fungus, Undifilum oxytropis. J. Microbiol. Methods 81, 160-165. doi: 10.1016/j. mimet.2010.02.015

Nakai, V. K., Rocha, L. O., Goncalez, E., Foneseca, H., Ortega, E. M., and Correa, B. (2008). Distribution of fungi and aflatoxins in stored peanut variety. Food Chemistry 106, 190-285. doi: 10.1016/j.foodchem.2007.05.087

Nesci, A. V., Bluma, R. V., and Etcheverry, M. G. (2005). In vitro selection of maize rhizobac-teria to study potential bio- logical control of Aspergillus section Flavi and aflatoxin production. Eur. J. Plant Pathol. 113, 159-171. doi: 10.1007/ s10658-005-5548-3

Ngindu, A., Kenya, P. R., and Ocheng, D. M. (1982). Outbreak of acute hepatitis by aflatoxin poisoning in Kenya. Lancet 319, 1346-1348. doi: 10.1016/S01406736(82)92411-4

Nielsen, H. B., Sonne, A. M., Grunert, K. G., Banati, D., Pallak-Toth, A., Lakner, Z., et al. (2009). Consumer perception of the use of high-pressure processing and pulsed electric field technologies in food production. Appetite 52, 115-126. doi: 10.1016/j.appet.2008.09.010

Oyelami, O. A., Maxwell, S. M., Adelusola, K. A., Aladekoma, T. A., and Oyelese, A. O. (1995). Aflatoxins in the autopsy brain tissue of children in Nigeria. Mycopathology 132, 35-38. doi: 10.1007/BF01138602

Palumbo, J. D., Baker, J. L., and Mahoney, N. E. (2006). Isolation of bacterial antagonists of Aspergillus flavus from almonds. Microb. Ecol. 52, 45-52. doi: 10.1007/s00248-006-9096-y

Park, D. L. (2002). Effect of processing on aflatoxin. Adv. Exp. Med. Biol. 504, 173-179. doi: 10.1007/978-1-4615-0629-4_17

Paterson, R., and Lima, N. (2010). How will climate change affect mycotoxins in food? Food Res. Int. 43, 1902-1914. doi: 10.1016/j.foodres.2009. 07.010

Paterson, R., and Lima, N. (2011). Further mycotoxin effects from climate change. Food Res. Int. 44, 2555-2566. doi: 10.1016/j.foodres.2011.05.038

Paterson, R., and Lima, N. (2012). "Climate change, fumonisins and animal feed," in Nutrieconomics: Balancing Global Nutrition and Productivity, ed. E. M. Binder (Tulln: BiominWorld Nutrition Forum), 241-247.

Payne, G. A., and Brown, M. P. (1998). Genetics and physiology of aflatoxin biosynthesis. Annu. Rev. Phytopathol. 36, 329-362. doi: 10.1146/annurev.phyto. 36.1.329

Payne, G. A., Nystrom, G. J., Bhatnagar, D., Cleveland, T. E., and Woloshuk, C. P. (1993). Cloning of the afl-2 gene involved in aflatoxin biosynthesis from Aspergillus flavus. Appl. Environ. Microbiol. 59, 156-162.

Piemarini, S., Micheli, L., Ammida, N. H. S., Palleschi, G., and Moscone, D. (2007). Electrical immunosensor array using a 96-well screen-printed microplate for aflatoxin B1 detection. Biosens. Bioelectron. 22, 1434-1440. doi: 10.1016/j.bios. 2006.06.029

Pitt, J. I. (2000). Toxigenic fungi and mycotoxins. Br. Med. Bull. 56, 184-192. doi: $10.1258 / 0007142001902888$
Prasher, D. C., Eckenrode, V. K., Ward, W. W., Prendergast, F. G., and Cormier, M. J. (1992). Primary structure of the Aequorea victoria green-fluorescent protein. Gene 111, 229-233. doi: 10.1016/0378-1119(92)90691-H

Price, M. S., Yu, J., Nierman, W. C., Kim, H. S., Pritchard, B., Jacobus, C. A., et al. (2006). The aflatoxin pathway regulator AflR induces gene transcription inside and outside of the aflatoxin biosynthetic cluster. FEMS Microbiol. Lett. 255, 275-279. doi: 10.1111/j.1574-6968.2005.00084.x

Qian, G., Tang, L., Guo, X., Wang, F., Massey, M. E., Su, J., et al. (2014). Aflatoxin B1 modulates the expression of phenotypic markers and cytokines by splenic lymphocytes of male F344 rats. J. Appl. Toxicol. 34, 241-249. doi: 10.1002/jat. 2866

Qureshi, H., Hamid, S. S., Ali, S. S., Anwar, J., Siddiqui, A. A., and Khan, N. A. (2015). Cytotoxic effects of aflatoxin B1 on human brain microvascular endothelial cells of the blood-brain barrier. Med. Mycol. 53, 409-416. doi: 10.1093/mmy/myv010

Reddy, B. N., and Raghavender, C. N. (2007). Outbreaks of aflatoxicoses in India. Afr. J. Food Agric. Nutr. Dev. 7, 1-15.

Reddy, K. R. N. (2010). An overview of mycotoxin contamination in foods and itsimplications for human health. Toxin Rev. 29, 3-26. doi: 10.3109/ 15569541003598553

Reiter, E., Zentek, J., and Razzazi, E. (2009). Review on sample preparation strategies and methods used for the analysis of aflatoxins in food and feed. Mol. Nutr. Food Res. 53, 508-524. doi: 10.1002/mnfr. 200800145

Romani, L. (2004). Immunity to fungal infections. Nat. Rev. Immunol. 4, 1-23. doi: $10.1038 /$ nri1255

Rooney-Latham, S., Janousek, C. N., Eskalen, A., and Gubler, W. D. (2008). First report of Aspergillus carbonarius causing sour rot of table grapes (Vitisvinifera) in California. Plant Dis. 92:651. doi: 10.1094/PDIS-92-4-0651A

Roze, L. V., Hong, S. Y., and Linz, J. E. (2013). Aflatoxin biosynthesis: current frontiers. Annu. Rev. Food Sci. Technol. 4, 293-311. doi: 10.1146/annurev-food083012-123702

Rustom, I. Y. S. (1997). Aflatoxin in food and feed: occurence, legislation and inactivation by physical methods. Food Chem. 59, 57-67. doi: 10.1016/S03088146(96)00096-9

Saalia, F. K., and Phillips, R. D. (2011a). Degradation of aflatoxins by extrusion cooking: effects on nutritional quality of extrudates. LWT Food Sci. Technol. 44, 1496-1501. doi: 10.1016/j.lwt.2011.01.021

Saalia, F. K., and Phillips, R. D. (2011b). Reduction of aflatoxins in peanut meal by extrusion cooking in the presence of nucleophiles. LWT Food Sci. Technol. 44, 1511-1516. doi: 10.1016/j.lwt.2011.02.012

Sanchis, V., and Magan, N. (2004). "Environmental profiles for growth and mycotoxin production, Chapter 8," in Mycotoxins in Food: Detection and Control, eds N. Magan and M. Olsen (Cambridge, MA: Woodhead Publishing Ltd), 174-189.

Schmidt-Heydt, M., Abdel-Hadi, A., Magan, N., and Geisen, R. (2009). Complex regulation of the aflatoxin biosynthesis gene cluster of A. flavus in relation to various combinations of water activity and temperature. Int. J. Food Microbiol. 135, 231-237. doi: 10.1016/j.ijfoodmicro.2009.07.026

Schmidt-Heydt, M., Parra, R., Geisen, R., and Magan, N. (2011). Modelling the relationship between environmental factors, transcriptional genes and deoxynivalenol mycotoxin production by two Fusarium species. J. R. Soc. Interface 8, 117-126. doi: 10.1098/rsif.2010.0131

Schmidt-Heydt, M., Rufer, C. E., Abdel-Hadi, A., Magan, N., and Geisen, R. (2010). The production of aflatoxin B1 or G1 by Aspergillus parasiticus at various combinations of temperature and water activity is related to the ratio of aflS to aflR expression. Mycotoxin Res. 26, 241-246. doi: 10.1007/s12550-010-0062-7

Schuster, E., Dunn, C., van Frisvad, J., and Dijck, P. W. (2002). On the safety of Aspergillus niger: a review. Appl. Microbiol. Biotechnol. 59, 426-435. doi: 10.1007/s00253-002-1032-6

Seo, J. H., Min, W. K., Kweon, D. H., Park, K., and Park, Y. C. (2011). Characterization of monoclonal antibody against aflatoxin B (1) produced in hybridoma $2 \mathrm{C} 12$ and its single-chain variable fragment expressed in recombinant Escherichia coli. Food Chem. 126, 1316-1323. doi: 10.1016/j. foodchem.2010.11.088

Severns, D. E., Clements, M. J., Lambert, R. J., and White, D. G. (2003). Comparison of Aspergillus ear rot and aflatoxin contamination in grain of highoil and normal oil corn hybrids. J. Food Prot. 66, 637-643. doi: 10.4315/0362028X-66.4.637 
Sharmila Banu, G., Kumar, G., and Murugesan, A. G. (2009). Ethanolic leaves extract of Trianthema portulacastrum L. ameliorates aflatoxin $\mathrm{B}(1)$ induced hepaticdamage in rats. Indian J. Clin. Biochem. 24, 250-256. doi: 10.1007/ s12291-009-0074-2

Shcherbakova, L., Statsyuk, N., Mikityuk, O., Nazarova, T., and Dzhavakhiya, V. (2015). Aflatoxin B1 degradation by metabolites of Phoma glomerata PG41 isolated from natural substrate colonized by aflatoxigenic Aspergillus flavus. Jundishapur J. Microbiol. 8:e24324. doi: 10.5812/jjm.24324

Sirot, V., Fremy, J. M., and Leblanc, J. C. (2013). Dietary exposure to mycotoxins and health risk assessment in the second French total diet study. Food Chem. Toxicol. 52, 1-11. doi: 10.1016/j.fct.2012.10.036

Squire, R. A. (1981). Ranking animal carcinogens: a proposed regulatory approach. Science 214, 877-880. doi: 10.1126/science.7302565

Stoloff, L., and Trucksess, M. W. (1981). Effect of boiling, frying, and baking on recovery of aflatoxin from naturally contaminated corn grits or cornmeal. J. Assoc. Off. Anal. Chem. 64, 678-680.

Sulyok, M., Beed, F., Boni, S., Abass, A., Mukunzi, A., and Krska, R. (2015). Quantitation of multiple mycotoxins and cyanogenic glucosides in cassava samples from Tanzania and Rwanda by an LC-MS/MS-based multi-toxin method. Food Addit. Contam. Part A Chem. Anal. Control, Expo. Risk Assess. 32, 488-502.

Tabari, M., Karim, G., Ghavami, M., and Chamani, M. (2011). Method validation for aflatoxin M1 determination in yoghurt using immunoaffinity column cleanup prior to high-performance liquid chromatography. Toxicol. Ind. Health 27, 629-635. doi: 10.1177/0748233710394236

Tandon, B. N., Krishnamurthy, L., Koshy, A., Tandon, H. D., Ramalingaswamy, V., Bhandari, J. R., et al. (1977). Study of an epidemic of jaundice presumably due to toxic hepatitis in North-West India. Gastroenterology 72, 488-494.

Teniola, O. D., Addo, P. A., Brost, I. M., Farber, P., Jany, K. D., Alberts, J. F., et al. (2005). Degradation of aflatoxin B1 by cell-free extracts of Rhodococcus erythropolis and Mycobacterium fluoranthenivorans sp. nov. DSM44556T. Int. J. Food Microbiol. 105, 111-117. doi: 10.1016/j.ijfoodmicro.2005.05.004

Torres, P., Guzman-Ortiz, M., and Ramirez-Wong, B. (2001). Revising the role of $\mathrm{pH}$ and thermal treatments in aflatoxin content reduction during the tortilla and deep frying processes. J. Agric. Food Chem. 49, 2825-2829. doi: 10.1021/ jf0007030

Townsend, C. A., Christensen, S. B., and Trautwein, K. (1984). Hexanoate as a starter unit in polyketide synthesis. J. Am. Chem. Soc. 106, 3868-3869. doi: $10.1021 /$ ja00325a031

Trail, F., Manhanti, N., and Linz, J. (1995a). Molecular biology of aflatoxin biosynthesis. Microbiology 141, 755-765. doi: 10.1099/13500872-141-4-755

Trail, F., Mahanti, N., Rarick, M., Mehigh, R., Liang, S. H., Zhou, R., et al. (1995b). Physical and transcriptional map of an aflatoxin gene cluster in Aspergillus parasiticus and functional disruption of a gene involved early in the aflatoxin pathway. Appl. Environ. Microbiol. 61, 2665-2673.

Umoh, N. J., Lesi, O. A., Mendy, M., Bah, E., Akano, A., Whittle, H., et al. (2011). Aetiological differences in demographical, clinical and pathological characteristics of hepatocellular carcinoma in The Gambia. Liver Int. 31, 215-221. doi: 10.1111/j.1478-3231.2010.02418.x

Van Egmond, H. P. (1991). Mycotoxins. Int. Dairy Fed. Spec. Issue 101, 131-135.

Veldman, A., Meijs, J. A. C., Borggreve, G. J., and Heeres van der Tol, J. J. (1992). Carryover of aflatoxin from cows' food to milk. Animal Production 55, 163-168. doi: $10.1017 /$ S0003356100037417

Verma, R. J. (2004). Aflatoxin causes DNA damage. Int. J. Hum. Genet. 4, 231-236.

Waliyar, F., Osiru, M., Ntare, B. R., Vijay, K. K., Sudini, H., Traore, A., et al. (2015). Aflatoxins in maize and other crops. World Mycotoxin J. 8, 245-252. doi: 10.3920/WMJ2014.1766

Waliyar, F., Osiru, M., Sudini, H., and Njoroge, S. (2013). "Reducing aflatoxins in groundnuts through integrated management and biocontrol," in Aflatoxins Finding Solutions for Improved Food Safety, eds L. J. Unnevehr and D. Grace (Washington, DC: International Food Policy Research Institute), 1-2.

Waller, J. M., Bigger, M., and Hillocks, R. A. (2007). Coffee Pests, Diseases and Their Management. Cambridge, MA: CAB International.

Weidenborner, M. (2001). Encyclopedia of Food Mycotoxins. New York, NY: Springer-Verlag.
Wen, Y., Hatabayashi, H., Arai, H., Kitamoto, H. K., and Yabe, K. (2005). Function of the cypX and moxY genes in aflatoxin biosynthesis in Aspergillus parasiticus. Appl. Environ. Microbiol. 71, 3192-3198. doi: 10.1128/AEM.71.6.3192-3198. 2005

Williams, J. H., Phillips, T. D., Jolly, P. E., Stiles, J. K., Jolly, C. M., and Aggarwal, D. (2004). Human aflatoxicosis in developing countries: a review of toxicology, exposure, potential health consequences, and interventions. Am. J. Clin. Nutr. 80, 1106-1122.

Wolf-Hall, C. (2010). "Fungal and mushroom toxins," in Pathogens and Toxins in Foods: Challenges and Interventions, eds V. K. Juneja and J. N. Sofos (Washington, DC: ASM Press), 275-285.

Wood, G. E. (1991). Aflatoxin M1, Mycotoxins and Phytoalexins. London: CRC Press, $145-163$.

Wu, F. (2010). The Global Burden of Disease Caused by Foodborne Aflatoxin. WHO Commissioned Report. Geneva: World Health Organization Food Borne Disease Burden Epidemiology Reference Group.

Wu, F., Bhatnagar, D., Bui-Klimke, T., Carbone, I., Hellmich, R., and Munkvold, G. (2011). Climate change impacts on mycotoxin risks in US maize. World Mycotoxin J. 4, 79-93. doi: 10.3920/WMJ2010.1246

Wu, S., Duan, N., Zhu, C., Ma, X., Wang, M., and Wang, Z. (2011). Magnetic nanobead-based immunoassay for the simultaneous detection of aflatoxin B1 and ochratoxin A using upconversion nanoparticles as multicolor labels. Biosens. Bioelectron. 30, 35-42. doi: 10.1016/j.bios.2011.08.023

Wu, Q., Jezkova, A., Yuan, Z., Pavlikova, L., Dohnal, V., and Kuca, K. (2009). Biological degradation of aflatoxins. Drug Metab. Rev. 41, 1-7. doi: 10.1080/ 03602530802563850

Yabe, K., Ando, Y., and Hamasaki, T. (1991). A metabolic grid among versiconal hemiacetal acetate, versiconol acetate, versiconol and versiconal during aflatoxin biosynthesis. J. Gen. Microbiol. 137, 2469-2475. doi: 10.1099/ 00221287-137-10-2469

Yabe, K., Chihaya, N., Hamamatsu, S., Sakuno, E., Hamasaki, T., Nakajima, H., et al. (2003). Enzymatic conversion of averufin to hydroxyversicolorone and elucidation of a novel metabolic grid involved in aflatoxin biosynthesis. Appl. Environ. Microbiol. 69, 66-73. doi: 10.1128/AEM.69.1.66-73.2003

Yabe, K., and Nakajima, H. (2004). Enzyme reactions and genes in aflatoxin biosynthesis. Appl. Microbiol. Biotechnol. 64, 745-755. doi: 10.1007/s00253004-1566-x

Yazdanpanah, H., Mohammadi, T., Abouhossain, G., and Cheraghali, A. M. (2005). Effect of roasting on degradation of aflatoxins in contaminated pistachio nuts. Food Chem. Toxicol. 43, 1135-1139. doi: 10.1016/j.fct.2005.03.004

Yu, J. (2012). Current understanding on aflatoxin biosynthesis and future perspective in reducing aflatoxin contamination. Toxins 4, 1024-1057. doi: 10.3390/toxins4111024

Yu, J., Bhatnagar, D., and Ehrlich, K. C. (2002). Aflatoxin biosynthesis. Revista Iberoam.Micol. 19, 191-200.

Yu, J., Chang, P. K., Ehrlich, K. C., Cary, J. W., Bhatnagar, D., Cleveland, T. E., et al. (2004). Clustered pathway genes in aflatoxin biosynthesis. Appl. Environ. Microbiol. 70, 1253-1262. doi: 10.1128/AEM.70.3.1253-1262. 2004

Zhao, L. H., Guan, S., Gao, X., Ma, Q. G., Lei, Y. P., and Bai, X. M. (2011). Preparation, purification and characteristics of an aflatoxin degradation enzyme from Myxococcus fulvus ANSM068. J. Appl. Microbiol. 110, 147-155. doi: 10. 1111/j.1365-2672.2010.04867.x

Conflict of Interest Statement: The authors declare that the research was conducted in the absence of any commercial or financial relationships that could be construed as a potential conflict of interest.

Copyright (c) 2017 Kumar, Mahato, Kamle, Mohanta and Kang. This is an openaccess article distributed under the terms of the Creative Commons Attribution License (CC BY). The use, distribution or reproduction in other forums is permitted, provided the original author(s) or licensor are credited and that the original publication in this journal is cited, in accordance with accepted academic practice. No use, distribution or reproduction is permitted which does not comply with these terms. 